\title{
ФОРМИРОВАНИЕ ПРЕДСТАВЛЕНИЙ О НАРОДНОЙ ЭТИКЕ В ЯЗЫКОВОЙ КАРТИНЕ МИРА МЛАДШЕГО ШКОЛЬНИКА
}

\author{
Forming Perceptions of Ethics in the Linguistic Worldview \\ of Primary Schoolchildren
}

Keywords: primary schoolchildren, paremia, proverb, Russian ethics, linguistic worldview

Contact: МГПУ; tatiana.voevodina.2017@mail.ru,rusinova_aleksandra@mail.ru

Каждый этнос приобретал опыт и знания в труде, наблюдениях за природой, окружающей средой и за взаимоотношениями людей. Словесным выражением этого стали пословицы, в которых отражен и закреплен многовековой социальноисторический опыт именно того или иного народа. В пословицах и поговорках нашла свое отражение вся многогранная жизнь народа, все сферы деятельности человека, его бытийного состояния. Пословичные выражения - сгусток трудового, нравственного и эстетического опыта этноса, сжатого в мудрые изречения. Именно поэтому с помощью пословиц можно приобщиться к образу мыслей народа, приблизиться к постижению своеобразия национального характера, национальной системы ценностей (Замалетдинов, Замалетдинова 2010: 73-78).

Термин «паремия» можно рассматривать как синоним пословичнопоговорных образований. В филологии паремии (пословицы и поговорки) трактуются как особый вид устойчивых высказываний, носящих образный характер, которые в сжатой форме выражают моральные нормы. В паремиях содержится житейский опыт, народная мудрость народа. Следовательно, через рассмотрение паремий познается не только язык, но и культура народа. Одним из свойств паремий является то, что они способны как отражать, так и порождать правила и нормы поведения человека в реалиях окружающего его мира.

Среди основных характеристик паремий можно выделить их краткость, цельнооформленность, наличие той или иной прагматической установки, 
жесткость структуры. Оценочный характер паремий, в основе которого лежит образ, является их неотъемлемой чертой (Гетман 2013: 316-320).

Отражая народную мудрость и ценностную картину мира русского народа, пословицы и поговорки отличаются высокой метафоричностью, образностью, чему способствует их двуплановость, наличие буквального и переносного смыслов; они способны выражать как авторитарную, так и гуманистическую этические системы (Буянова 2014: 60-62).

Пословицы и поговорки играют особую роль в создании языковой картины мира. Языковая картина мира - это фиксация отраженной действительности в языке, которая влияет на становление языковой личности. Природа значения пословиц тесно связана с фоновыми знаниями носителя языка, с его практическим опытом, а также с культурно-историческими традициями народа, говорящего на данном языке (Лобанова, Афонина 2019: 227-233).

Отметим, что в пословицах и поговорках в большей мере, чем в других языковых единицах, проявляется субъективный человеческий фактор, отражающий лингвокреативный потенциал человеческого мышления, и огромный потенциал особого типа коммуникации - межпоколенной (Буянова 2014: 60-62).

Современное общество ставит перед школой актуальные задачи в области нравственного воспитания - формирование у детей доброжелательности, уважительного отношения к истории и культуре своего и других народов, развитие эстетических потребностей, способности к самостоятельным поступкам и действиям, совершаемым на основе морального выбора, что также отражено в новых образовательных стандартах. Вместе с тем учителя отмечают, что испытывают затруднения в воспитании у детей нравственно-этических качеств: доброты, отзывчивости, искренности, сострадания, умения сопереживать и сочувствовать, т.е. тех качеств личности, которые имеют глубинную природную основу и слабо компенсируются другими качествами. В связи с этим необходимо эффективное использование воспитательного потенциала всех видов образовательной деятельности, объединение усилий школы, семьи и всего общества.

В период начальной школы развиваются формы мышления, обеспечивающие в дальнейшем усвоение системы научных знаний, развитие научного, теоретического мышления. Известно, что научные понятия становятся доступными ребенку не сразу. В частности, они могут быть долго непостижимы в системе, хотя каждое из них порознь и понятно ребенку. Именно в начальной 
школе необходимо специально формировать у младших школьников представления о языковой картине мира, т.е. комплекс знаний о мире, отражающих мировоззрение народа и заключенных в языке, в значениях слов. Чем глубже познает ребенок родной язык, тем шире и разнообразнее картина мира в его сознании. Поскольку проблема формирования представления о языковой картине сложна и многогранна, то мы в своей статье останавливаемся на одном аспекте данной проблемы, а именно на формировании представлений о народной этике в языковой картине мира младшего школьника посредством паремий.

По мнению ведущих отечественных лингвистов, в русской языковой картине мира ключевыми оказываются идеи ценности семьи, важности родины, сущности добра, значимости человеческих отношений, справедливости. С этими идеями связано множество пословиц, имеющих различную смысловую нагрузку. Именно с них можно начать работу над формированием представлений о языковой картине мира у младшего школьника. Разберем на примерах те взгляды, которые вкладывались русским народом не одну сотню лет.

Семья - один из концептов, которому следует уделить внимание.

Сила семьи отражается в следующих пословицах: Вся семья вместе, так и душа на месте.; Где семья дружна, не страшна беда.; Человек семьею крепок.; В недружной семье добра не бьвает.; В семье дружат - живут не тужат.; В семье разлад, так и дому не рад.; Когда семья вместе, и сердие на месте. Такими паремиями иллюстрируется значимость семьи для каждого человека - это залог счастливой жизни, ведь стабильность, спокойствие, любовь поддерживает всех членов семьи, вот почему люди могут вместе справиться со всеми невзгодами и быть по-настоящему счастливыми.

Прощение и понимание в семье: В семье не без урода.; В семье все бывает.; В одной суме - да разные денежки; в одной семье - да разные детушки.; Намеки да попреки - семейные пороки.; На что и клад, когда в семье лад.; Семейное согласие всего дороже. Как уже упоминалось, семья - это важная составляющая жизни любого человека, но самое первостепенное - наличие понимания у членов семьи, умения прощать друг друга и принимать такими, какими есть.

Следующий концепт, который не обладает такой большой моральной составляющей, но являющийся частью русского менталитета - богатство.

В русском менталитете заложено довольствоваться меньшим: Не думалось жить богато, да пришлось.; Не жили богато, нечего и начинать. Бедность народа - это естественное состояние. И если человек вдруг разбогател, а затем 
потерял все свое богатство, то считается, что это знак, что ему привычнее жить небогато.

Богатство - счастье: Богатый как хочет, а бедный как может.; Богатство открывает и двери, и замки.; Богатому везде радыл. В русском языке сложно найти пословицы, где богатство представляется как положительный аспект жизни, потому что, как уже упоминалось ранее, большинство людей к этому не склонны. Говоря о приведенных выше единицах, их главное значение в том, что богатство дает свободу в выборе, даря возможность заниматься тем, что нравится, не задумываясь о завтрашнем дне.

Перейдем к следующему концепту - дружба: Дружба да братство дороже всякого богатства.; Дружба - дело святое.; Без дружбы нет счастья.; На дружбе мир держится.; Дружба крепка не лестью, а правдой и честью.; Дружба солдатская крепче каменных стен.; Дружбой дорожи, забывать ее не спеши.; Потому хорошо живется, что дружба народов в нашей стране ведется.; Дружба народов увеличивает их силу.; Народная дружба и братство дороже всякого богатства.; Если дружба велика, будет Родина крепка. Большое количество пословиц посвящено именно дружбе, потому что она помогает человеку стать лучше. Каждый из нас обретает в товарище родственную душу и опору. Даже если мы обратимся к истории, именно благодаря дружбе удалось преодолеть все трудности, которые постоянно сопровождали русский народ (революции, войны), поэтому это оставило неизгладимый след в русском менталитете.

Теперь рассмотрим еще один концепт - добро: Добрые слова лучше мягкого пирога.; Жизнь дана на добрые дела.; Про доброе дело говори смело.; Свет не без добрых людей.; Кто любит добрые дела, тому и жизнь мила.; От добра добра не ищут.; Сделав добро, не хвались. Доброта является ценным качеством человека, возвышающим его. Это качество позволяет человеку оставаться человечным.

Воззрения русского народа определяли в себе гуманистические идеи. В себе они несли оптимально сбалансированные соотношения внешнего воздействия через правила социального поведения, норм общества и внутренних психических возможностей, возрастных особенностей, индивидуальности детей. Воспитательные средства народной культуры отражают по своей сути социальноличностный ориентир. И можно сказать, что в современном мире приобщая детей к народным традициям русской культуры, мы формируем постепенно возрастные нормы поведения. Происходит самовоспитание ребенка, так как, осторожно исследуя границы дозволенного, он решает свои эмоциональные проблемы. Ведя 
последовательно работу в познании нравственно-этических норм, опираясь на опыт предков, можно сделать заключение о том, что дети не только теоретически различают понятия добро и зло, любовь и ненависть, правду и ложь, но и в жизни стремятся проявлять положительные качества души (Диденко 2015: 52-54).

С.В. Лихачев отмечает, что в период обучения необходимо «специально формировать у младших школьников представления о языковой картине мира, т.е. комплекс знаний о мире, отражающих мировоззрение народа и заключенных в языке, в значениях слов» (Лихачев 2017: 16-19).

При определении тематических групп для организации работы с паремиями необходимо исходить из «социального заказа» общества о воспитании подрастающего поколения. В настоящее время обществу необходимо молодое поколение, которое будет не только следовать нравственноэтическим нормам, но и сохранит в себе этические нормы русского народа.

При анализе паремий можно выявить особенности русского менталитета. Обращаясь к опыту наших предков, можно увидеть, что оптимизм и жизнелюбие ценилось с давних времен. Они считались основой для положительного поведения людей. В менталитете русского народа заложено милосердие, сотворение добра другим, что нельзя быть счастливым, если рядом беда. Традиции русской народной культуры - вот источник, который поможет решить нравственноэтические задачи с детьми. Эффективность формирования эстетического опыта младших школьников средствами народных пословиц и поговорок в значительной мере зависит от создания оптимальных условий педагогического руководства учебно-воспитательным процессом. Такими условиями следует считать: учет возрастных особенностей младших школьников; определение оптимального объема информации для младших школьников о народных пословицах и поговорках; создание положительной эмоциональной атмосферы в процессе восприятия и изучения младшими школьниками народных пословиц и поговорок; методическое обеспечение процесса их освоения.

Пословицы должны стать для младших школьников образцом речи, передачи мысли кратко и точно, без избытка информации и использования излишнего количества слов. Также видится целесообразным формировать осознанное отношение к пословицам и поговоркам как средствам обогащения собственного жизненного и формирования нового эстетического опыта (Чужа 2016: 136-140). Менталитет русского народа в полной мере находит отражение в паремиях, которые в свою очередь несут в себе морально-нравственные нормы и информацию о жизни предыдущих поколений. Несомненно, знакомясь 
с пословицами, младший школьник познает особенности русского народа и приобретает свою языковую картину мира, в которой так или иначе будут отражены моральные нормы и народная лексика. Таким образом, подтекст, который доносят данные пословицы, оказывает значительное влияние на формировании представлений о народной этике в языковой картине мира младшего школьника.

\section{Summary}

To summarize all of the above, we guess that the study of proverbs in primary school is an integral part of education. The study of paremias really helps to form the linguistic worldview of the younger student. The article discusses concepts such as family, friendship, goodness, etc. Through them, children gain knowledge about the people, culture and morality. Thus, proverbs convey folk ethics and give the child those ideals that are necessary in modern society.

\section{Литература}

Буянова, Л.Ю. Русские пословицы и поговорки как этнокультурные константы: ментально-аксиологический аспект. Вестник Новгородского государственного университета. 2014 (77), с. 60-62.

Гетман, А.А. Паремии как воплощение концепта «Бедность». Мир науки, культуры, образования. 2013 (6/43), с. 316-320.

Диденко, И.А. Традиции русского народа в воспитании нравственно-этических норм поведения. In: Диденко, И.А. (ред.) Актуальные вопросы современной педагогики: материаль VI Международной научной конференции. Уфа, 2015, c. 52-54.

Замалетдинов, Р.P., Замалетдинова, Г.Ф. О роли пословиц в исследовании национально-культурных особенностей языкового сознания. Филология и культура. 2010 (2/20), с. 73-78.

Лихачев, С.В. Формирование у младших школьников представлений о языковой картине мира. Начальная школа. 2017 (1), с. 16-19.

Лобанова, Т.А., Афонина, Е.О. Роль противительных отношений в раскрытии национального своеобразия языковой картины русского мира (на материале сборника В.И. Даля «Пословицы русского народа»). In: Коптелова Н.Г., Котлов, А.К. (ред.) Духовно-нравственные основы русской 
литературы. Сборник научных статей конференции (Кострома, 19-20 апреля 2019 г.). Кострома: Костромский государственный университет, 2020 , c. $227-233$.

Чужа, Н.П. Формирование эстетического опыта младших школьников средствами народных пословиц и поговорок. Wschodnioeuropejskie Czasopismo Naukowe. 2016 (10), c. 136-140. 